\title{
抄紙機における微生物問題の診断について
}

\author{
オンデオナルコ カンパニー ○リンダ・ロバートソン \\ オンデオナルコ ジャパン株式会社 石 井 康 正
}

\section{Diagnosis of Microbial Problems on Paper Machines}

\section{Linda R. Robertson}

Principal Consultant Paper Microbiology ONDEO Nalco Co., Ltd

\section{Yasumasa Ishii}

Senior Account Manager ONDEO Nalco Japan Co., Ltd

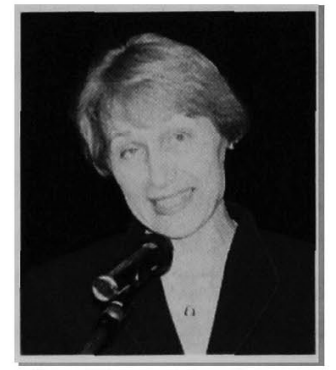

リンダ・ロバートソン

\begin{abstract}
Numerous microbes are capable of growth in paper machine systems. They form visible deposits that result in sheet defects. holes or even breaks in the web. Microbes are also responsible for performance loss and spoilage of pulp and expensive functional chemicals. This spoilage can lead to strength loss in fibers. formation of odors that result in rejected products, viscosity loss in starch and a variety of other problems. Diagnosis of microbial problems in complicated by the fact that simple aerobic plating techniques on tryptone glucose extract agar or Petrifilms ${ }^{\mathrm{TM}}$ with a 48-hour incubation period do not allow recovery of all of the microbes causing the problems. Nor do the numbers of planktonic (free-swimming) cells correlate to the severity of deposition on surfaces. This paper will discuss the limitations of generally accepted plating techniques and propose more accurate diagnostic methods for solving microbial problems.
\end{abstract}

分類： $M_{1}$ 抄紙・抄紙機一般， $W_{13}$ スライムコントロール剤

\section{1. 緒言}

抄紙系には炭水化物が多く温度が高いため, 多よう な微生物に理想的な增殖条件を提供している。微生物 の增殖を抑制しない場合は、デンプン, タンパク質, ラテックス及び炭酸カルシウム等の高価な添加剂が腐 敗する可能性がある。酸素がない状態で増殖する嫌気 性菌は䄉維の強度を低下させたり有毒な爆発性ガスを 発生させたりする可能性がある。

微生物は，バイオフィルムと呼ばれる污九を形成し て装筑表面に付着する (図 1,図2)。この污れは, 填

平成 14 年度年次大会講演（講演 No. A 20）
料，䄉維及び他の製紙用添加剤を取込むと更に大きく なる。通常の洗浄作業や加熱した苛性での洗浄以外の 時点で污れが剥離すると, シート欠陥や穴の発生及び 断紙も生じることがある。

これにより，装置を洗浄するために長時間の運転停 止を招いたり，低価格あるいは眅売できない製品にな ったりする。ここで, 微生物が抄紙機にみられる全て の污れの原因という分けではない。水系での化学的な 変化により, 微生物污れと外見や感触が似ている硫酸 バンド污れが発生することがある。

また，サイズ郕も污れを形成することがある。同様 にコートブロークや回収パルプからのピッチ, 及び粘 着性粒子も污れを形成することがある。更に, 歩留り 


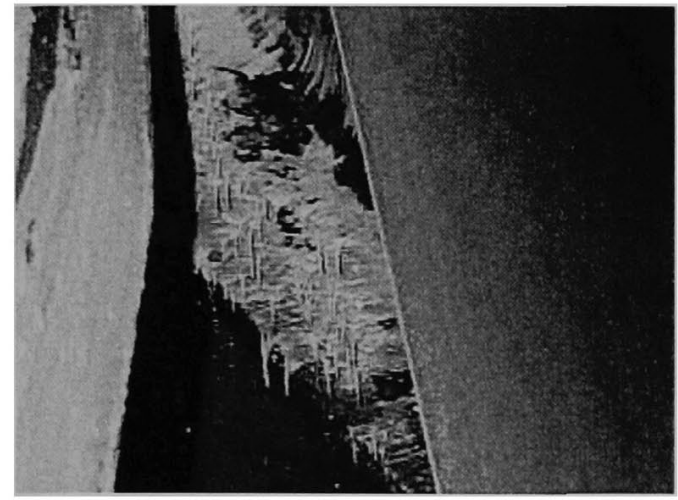

図 1 フエルト・セーブオールでの線状污れ

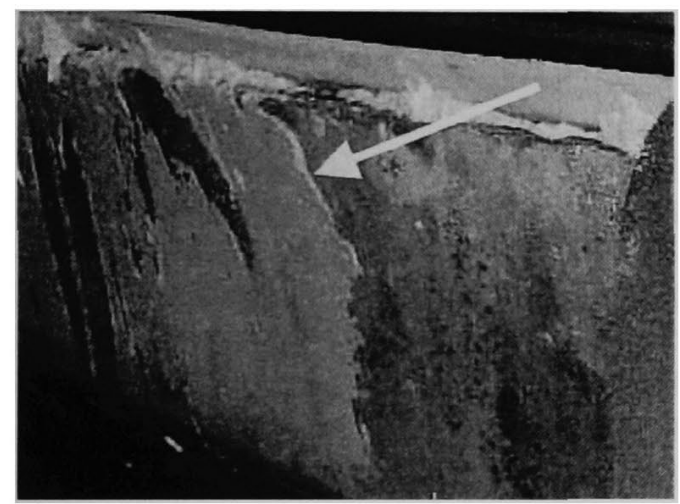

図 2 デュオフォーマー・トレイ上の微生物性の污れ

が悪い場合には微細粒子がシートに保持されず污れが 生じることもある。

抄紙機中の水に存在する微生物は, 浮遊性 (Planktonic）と呼ばれる。この種の微生物は,ヘッドボッ クスまたはブローク試料を採取して, フレート培羪法 (平板培盖法)によって検出・計測される。これら微 生物の負荷量は, アデノシン三リン酸 (ATP) 分析 を用いても湘定される。これに对して, 表面表面に付 着してパイオフィルムを形成する微生物は定着性 (Sessile) と呼ばれる。

装置表面に定着することは, 微生物にとって好都合 である”。多ような栄盖物と適切な酸素条件が得られ ることで, 抄紙機系の水中では生息できない種類の微 生物であっても急速に增殖することが可能になる。

抄紙機表面に定着した細菌は, 浮遊性の種類に比へ て殺菌剂に対する抵抗力がはるかに高い。最近の研究 では, 椱数の微生物種が混在するパイオフィルムが代 謝的に協力し, 細胞間の信号伝達を行っていることが 示されている。これは定着性の細胞にとって更に有利 となる゙。

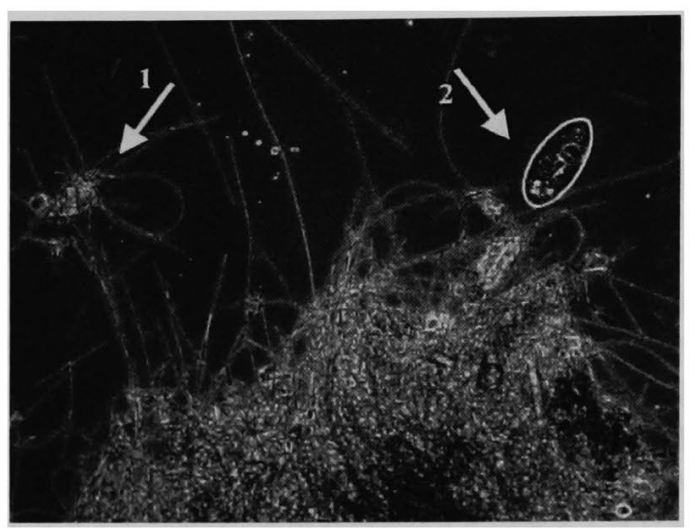

図 3 ライナーマシンから採取された線状污れの 400 倍位相㩆微鏡写真。填料物質に系状性細菌が結 合している。矢印 1 は系状性細菌の塊を示す。 矢印 2 は縺毛のある原生動物を示す（400 倍）

抄紙機の污れの中に存在する微生物の多くが, トリ プトングルコース寒天培地等のような標準プレート培 盖法やペトリフィルム (Petrifilms $\left.{ }^{\mathrm{TM}}\right)$ 培養法では增 殖できない。通常の 48 時間培養時間内では増殖でき ず,プレート培地またはフィルム培地上でコロニーを 形成するまで数日以上を要する微生物も生息している。 これらの要因のため, 好気性細菌播種法だけに依存す ると污れの形成原因について誤診を招き、誤った判断 と不適切な対策を行ってしまうことがある。

水質は, 各種製紙用添加剂やパルプの性能に影響を 与える。抄紙機に供給される水は, 系内に生息する多 種微生物の侵入経路となっている。不適切な水処理は, 装置の清浄性や操作性及び最終製品の品質に悪影響を 与える可能性がある。

糸状性細菌, 原生動物, 藻類及び線虫類等は, 工場 に供給される清水を介して抄紙機に混入する。これら は，一般に清水污染物（fresh water contaminants）と 呼ばれる。このクループの中で最も防除困難な微生物 が糸状性細菌（図3）である3!。

\section{2. 万法}

影微鏡検査は，位相差装置付きのオリンパスまたは ライカ顥微鏡を用いて行った。検査では，先ず 100 倍 の倍率で污れの全般的構成を観察し, その後 400 倍の 倍率で詳細観察及び同定を行った。

これと共に, 好気性菌の培養検査をペトリフィルム 及び Bactoトリプトングルコース寒天培地で行っだ。 培養は $37^{\circ} \mathrm{C}$ で少なくとも 48 洔間，あるいは 7 日間ま で行った。真菌検查は ONDEO Nalcoの自社製寒天培 
地で培養期間を 5 日間として行った。嫌気性の硫化物 生成細菌を分別するために，自社製培地で硫酸塭還元 性細菌を確認した。培養時間は2〜5 日であった。

\section{3. 結果及び考察}

微生物問題の診断は, システム全体の検查から始ま る。これには，個々の問題を解決することを目的とし た適切な評価方法の選択が必要となる。そして, 水系 及び原料系のフローダイアグラムを作成することが重 要である。このダイアグラムはシステムにおける特別 の水流や添加凨の影䈏を理解するための指標になる。

プレート式による好気性菌数測定結果によって，単 一の水流が污染されているのか、あるいは全水系が微 生物增殖を制御できていないのかを判断できる。

これらの結果によって，腐敗が起こる場所も分かる。 嫌気性菌は，酸素がない場合に增殖して重大な腐敗の 原因となる。嫌気性菌の検査には，增殖を促すための 専用培地または酸素を除去する培盖装置を必要とする。

\section{4. 清 水}

清水は抄紙機で使用される最大の添加剤である。こ の水質は，抄秖機の操作性及び最終製品の品質に大き な影籍を与える可能性がある。清水の 20〜100 CFU/ $\mathrm{ml}(1 \mathrm{ml}$ 中のコロニー・フォーミング・ユニット) の数值をへッドボックス中の 100 万 $\mathrm{CFU} / \mathrm{ml}$ と比較 すると，清水の菌数は妥当なものであると思われる。 残念なことに，表面の粘着性污れを形成する微生物の 多くは，好気性の TGEプレート培養法や好気性のペ トリフィルム培養法では增殖しない。

これらには, 系状性細菌, 原生動物, 線虫類, 及び 多種の真菌が含まれる。これらは培地では增殖し難い ので，実際の数值より低くなってしまう。このような 検查方法により得られた結果では, コストが高い割に は効果のない不適切な殺菌郕処理になってしまう可能 性があることを意味している。図4 に系状性細菌によ るオレンジ色線状活れの極端な例を示す。

以下に，不適切に処理された清水によって生じる問

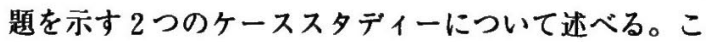
れらのケーススタディーにおいて，問題解決する際に 得られた情報の多くが位相差顕微鏡によるものであっ た。位相差顕微鏡によって，通常の顕微鏡では見えな い構造が見える。問題の発生原因を愦診させない様に， 試料は乾燥または染色をせずに直接観察された。

4.1 ケーススタディー1

当該アルカリ性上質紙製造装置のヘッドボックスの 好気性菌数は $10,000 \mathrm{CFU} / \mathrm{m} l$ 未満であった。真菌数

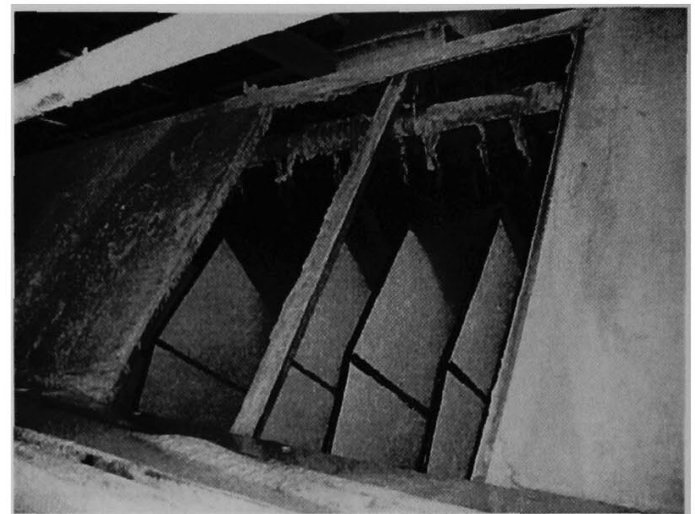

図４アルカリ性上質紙製造装置におけるセーブォー ルのポリディスク・フィルターでの系状細菌に よるオレンジ色線状污れの極端な例

は $10 \mathrm{CFU} / \mathrm{ml}$ 未満であっだ。これらは一般に「低い」 と考えられる菌数であり，大半の上質紙製造装置にお いては許容限度内である。しかし，抄紙機はオレンジ 色の線状污れに覆われていた。位相差顕微鏡での観察 によって，污れが填料とフィブリルを結びつけた紎 性細菌の塊で構成されていることを示した。系内の菌 数は非常に低かったが, 清水の菌数は $20 〜 40 \mathrm{CFU} / \mathrm{m} l$ の範囲であった。清水は塩素处理されており0.3〜0.5 $\mathrm{ppm}$ の残留遊離塩素量が記録された。供給される水 にはマンガンと鉄が含まれていた。残留塩素検查は， マンガンの干涉による測定への悪影響を考慮せずに行 われていた。これは塩素の「疑」陽性を生じる可能性 がある。また，処理に用いた塩素ガスは清澄水槽出口 の清水に加えられていたため, この水が抄紙機で使用 される迄の接触時間は $2 \sim 3$ 分だけであった。そのた め, 多くの系状性細菌が生存出来た。酸化剂処理を適 切に行うには濃度, 接触時間及び $\mathrm{pH}$ が重要である。 接触時間が短く $\mathrm{pH}$ が高い場合でも，活性の高い臭素 等の酸化夙は速やかに殺菌作用を発揮する。多くの采 状性細菌は，縕胞を保護する鞘構造を有している（図 5)。従って，系状性細菌を殺すために殺菌剂や酸化剂 は，鞘と細胞壁の双方を通過しなければならない。こ れが，鞘構造を有する系状性細菌の殺菌が困難な理由 の一つである。

従来の殺菌片の使用によって抄紙機での系状性細菌 の增殖は抑制可能である。または，デポジットコント ロールポリマー（無毒性の污れ防止用のポリマー）に よっても，污れの形成を抑制することができるがコス トが高い。清水の処理によって抄紙機への侵入を防ぐ 方がはるかに低コストである。 


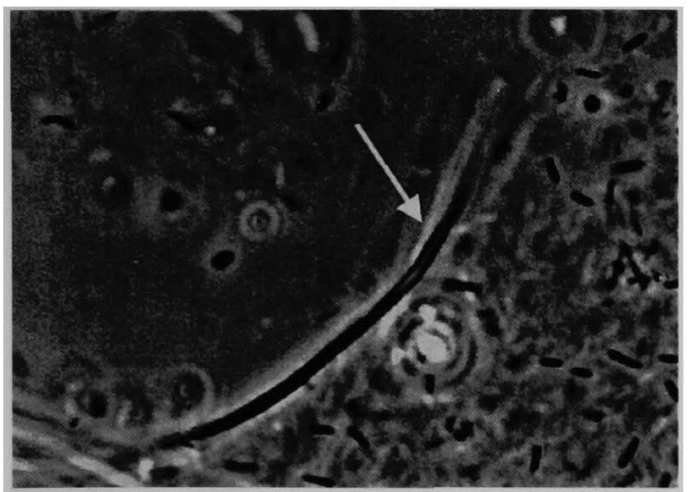

図 5 鞘構造（矢印）及び多糖類のスライムによって 囲まれている個々の単細胞細菌の位相影微鏡写 真 $(1,000$ 倍 $)$

\section{2 ケーススタディー2}

この工場には，高品質のアルカリ紙を製造する 2 機 の上質紙製造装㯰があった。総生産高は両装䈯で約 500 TPD であった。紙は表面サイズ処理されていた。 また, 灰分の歩留り（ワンパス・リテンション）は約 $80 \%$ であった。抄紙機での推定清水使用量は紙 1 卜 ンあたり 9 トンであった。これは，上質紙製造として は非常にクロースド化されていると言える。殺菌剤プ ログラムとしては，自社製酸化肪及び非酸化性有機殺 菌剂が使用されていた。抄紙機の加熱苛性洗浄は 4 6 週間毎に行われていた。抄紙機フレームにもセーフ オールにも，非常に僅かな污れしか認められなかった。

微生物の数は, 抄紙機及びチェストの試料採取部位 では非常に少なかった。しかし，清水処理における微 生物コントロールは不十分であることが多かった。菌 数は一定せず, 塩素処理装置の能力を超えることが多 かった。

ここで，この抄紙機では最終製品での淡青色欠点の
発生と言う未解決の問題を抱えていた（図6)。殺菌 剤プログラムの改善によって久点の数は経時的に減少 した。しかし, 清水処理工程でのクラリファイヤーの 界面が「浮き上がった」場合や，季節的には秋に依然 多かった。また，多量の碎片（debris）や硫酸バンド フロック等がキャリーオーバーされた場合に多数の欠 点が現れる傾向があった。そして，清水フィルターべ ッドからのキャリーオーバーが起こった場合，青色の 欠点が 2 4 日以内に認められ，キャリーオーバー後 4 日以内に抄紙機全体を加熱した苛性で洗浄する必要 があった。

紙の久点は小さく, 1 3.5 mm の範囲であり, 色 は淡青色であった。時折り褐色の欠点が現れた。これ らは化学分析によって，硫酸バンドによって生じる傾 向が示された。12 力月間に工場は青色の欠点によっ て 1,600 トンの紙を損失した。これは，利益では 375,000 USドル（約 4,870万円）に相当した。また 紙中の夾雑物の量も多かった。

現場の対策サポートチームは，原因となる微生物を 分離するために，プレート培養法を用いて問題を解決 しようと試みた。青色のシート欠陥は, 微生物の増殖 を示唆する IR シグナルを頻繁に示したが，高い菌数 值とシート久陥数の増加の間には相関関係は認められ なかった。

プレート培養法での菌数値と IR 分析に重点をおい た従来の方法では，問題を解决できなかった。そこで， 位相差顕微鏡を用いる他の方法が試みられた。この方 法では, 清水タンクから抄紙機污れの部位までのシス テム全体の試料，及び抄紙機系で使用されている全て の添加剤試料が採取された。シート中に発見された変 色欠陥を再現するために，污れと各種染料が組合わせ られた。

抄紙機污れの検査によって，清水の大きな問題が確
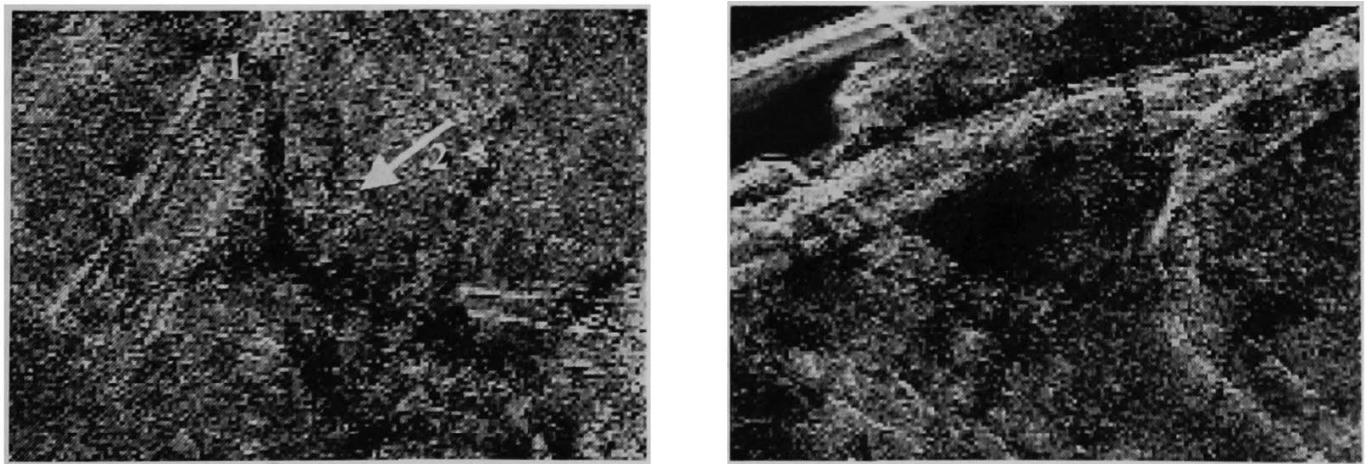

図 6 青色の众点を伴うシート部の顕微鏡写真。矢印 1 は木の織維を示す。矢印 2 は黒い織維状の網を示す。 


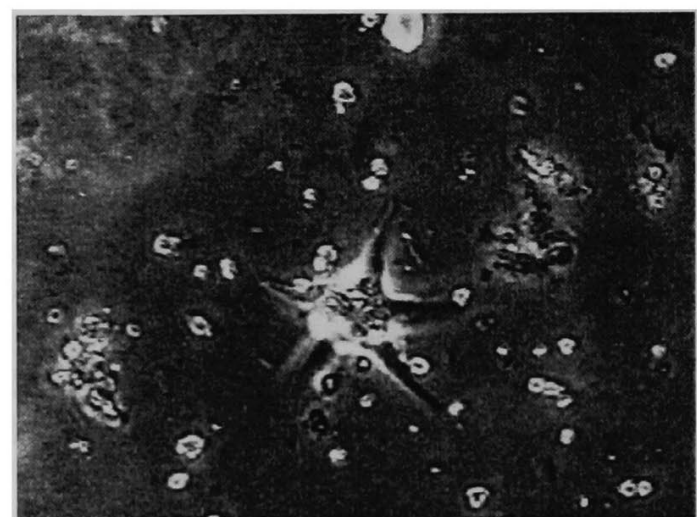

図 7A 抄紙機付着物及び填料と有殼アメーパ $(400$ 倍）

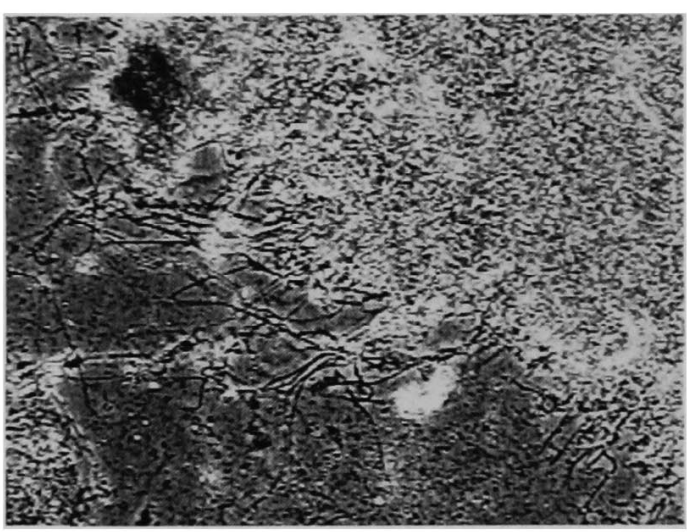

図 7 B 系状性細菌及び填料（400 倍）

認された。抄紙機からの污れには填料, 樴維, アメー バ, 原生動物, 及び系状性細菌の塊（図７Ａ及び B） を含んでいた。系状性細菌，アメーバ及び原生動物の 存在は, 清水処理が不十分であることを示している。 しかも他の多くの工場と比較した場合, 残念なことに この工場には固形物を除去するためのサンドフィルタ 一が設置されていなかった。このため，更に問題が拡 大した。また, 清水の検査によって供給される清水中 には微生物の混入が確認された（図 8)。染料タンク からの微生物を伴う污れ真菌も観察された（図 9)。

滤過清水は，硫酸バンドに起因したフロック粒子を 含んでいた。これらは真菌の菌糸によって強く污染さ れていた。清水と抄紙機の双方から探取した硫酸バン ド污れは，微生物によって強く污染されていた（図 10)。また, 而力の硫酸バンド源が多量の真菌, 単細 胞細菌及び系状性細菌を含んでいた。硫酸バンドはカ チオン性であり，この工場で使用されている青色染料

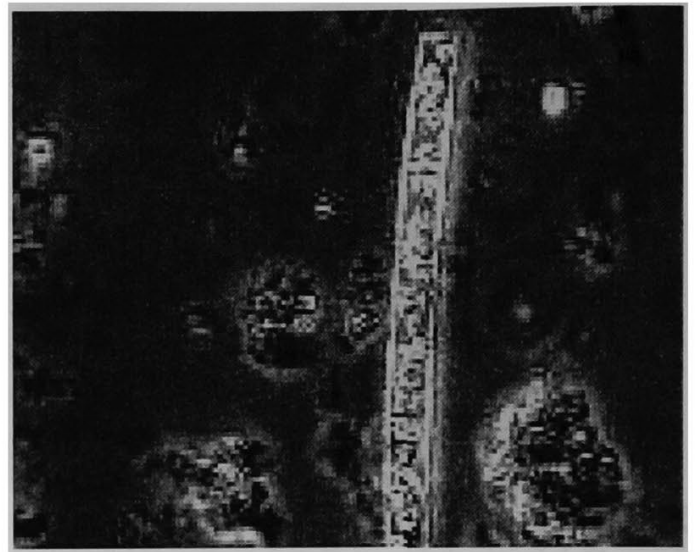

図 8 清水中の硫酸バンドフロック及び生存藻類 $(400$ 倍）

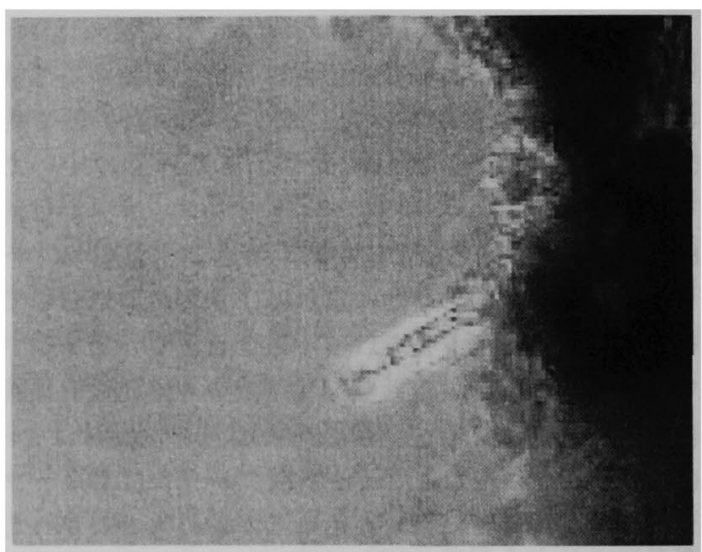

図 9 染料タンクからの微生物を伴う活れ。真菌も観 察された（400倍）

はアニオン性である。

紙中の青色欠点の顕微鏡検査でフロック状粒子,及 び真菌と類似の分畦構造が示された（図 6）ことや， 青色染料污れの中に真菌が認められ，同様に硫酸バン ドによるフロック粒子中にも真菌が認められたこと （図 10）から，これらが互いに結合している可能性が 高い。これら検查から, 硫酸バンドがアニオン性の青 色染料を吸着して深青色に変化したと判断された。こ の硫酸バンドフロックを含む水は，染料を希釈するた めに使用されていた。

抄紙機污れも青色染料による染色で淡青色に変化し た。この染料は, 非常に低濃度で添加しているので, 青色染料がどの様に抄紙機污れを青変させるのかを見 るのは困難である。これに対して, 濃縮青色染料, 凝 結剂, 硫酸バンド及び製紙原料が相互作用しているこ とが考えられる。当該システム中の真菌は自然状態で 

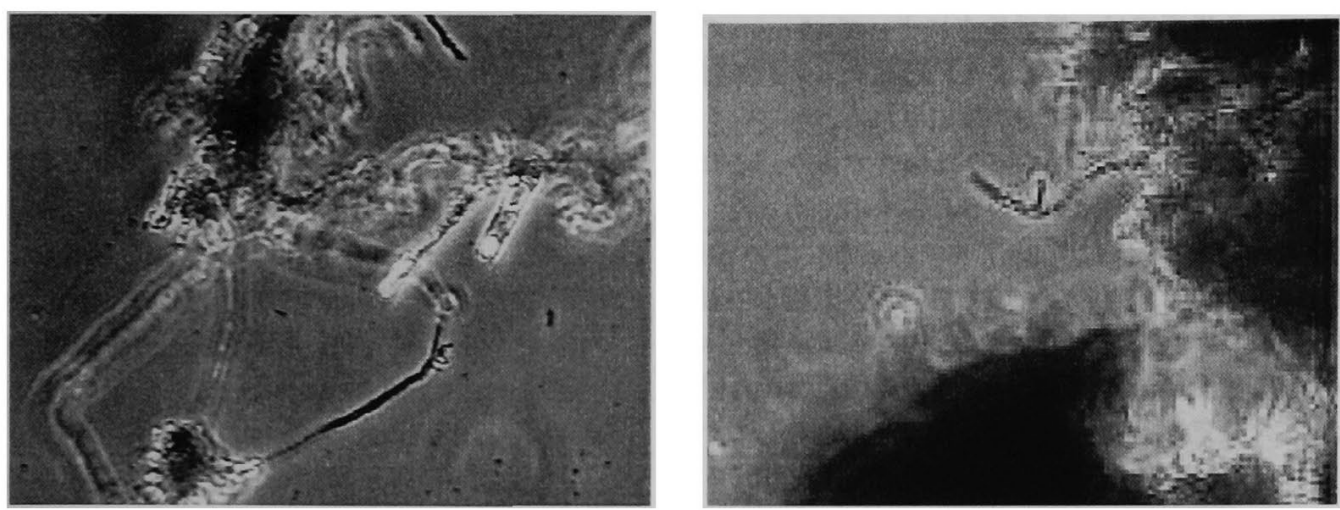

図 10 アニオン性青色染料で染色した清水中の硫酸バンドフロックとフロック粒子中の真菌（400 倍）

は青くなかったが，青色に染色される可能性がある。

顥微鏡検査と問題解決法によって, 問題の原因が明 らかにされた。不十分な清水処理, 硫酸バンドのキャ リーオーバー,及び污染された水による青色染料の希 釈等の組合せによって青い欠陥が生じたと判断された。 染料システムが, 直ちに加熱した苛性で洗浄された。 また, 清水中の残留酸化剂を増加さし, 滤過処理を改 善するための長期計画が考虑された。そして, 通常で は青色の欠点が多数発生する季節である 3 力月間に, 青色の欠点は全く認められなかった。夾雑物によるシ ート中の欠点も減少した。

現場の技術責任者は, 工場での水処理プログラムを 改善しようと, 長年にわたって努力してきた。工場は 問題があることは分かっていたが, 調査が完了して問 題が改善されるまで,この不十分な涺過処理及び清水 処理がどれほど経済的に悪影慗を与えるのか認識して いなかった。

この工場では, 改善が行われた後の 10 ケ月間は青 色の欠点が現れなかった。この結果,この工場におい

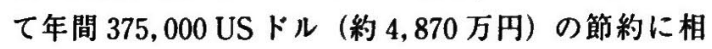
当する経済的な効果を上げた。

\section{5. 腐敗}

抄紙機表面に污れが見られない場合でも，嫌気性菌 が問題を生じるこがある。製紙業界では，酸素がな い条件下で生息する微生物の增殖が抑制されなかった ために，数名が死亡した例がある゙。高く深いチェス トや水が長く滞留してしまう系では，これら微生物を 理想的に增殖させてしまう。

嫌気性菌の問題は, 製紙業界が指向している水のク ロースド化及び䋞維のリサイクル量の増加に伴って增 加している ${ }^{6}$ 。3 番目のケーススタディーでは, 嫌気
性菌が增殖することで起きる腐敗が安全性を損なう危 険を招くことを示す。嫌気性菌の增殖は, 緎維の強度 を低下させたり，填料を増加させたり，コーティング 粘度に悪影響を及ほす可能性がある。更に，硫化水素 や水素などの有毒な爆発性ガスを発生させる可能性も ある。

\section{1 ケーススタディー 3}

第 3 のケーススタディーは, 特別な事例である。こ の工場では，毎日 1,500 トンの 3 層の板紙を製造して おり, 工場労働者から硫化水素の存在に対しての苦情 があった。この抄紙機には污れが見られなかった。ま た, 存在する污れ欠点の周辺に糸状性細菌に由来する ものが認められないことから，適切に清水処理されて いると判断された。抄紙機には，微生物による污れに 起因した操作上の問題は皆無であった。

この抄紙機での加熱苛性洗浄の間隔は, 通常の操業 では約 3 ケ月間であった。ここでは，段ボール古紙 （OCC）を原料とする装置であればどこでも見られる ような粘着性物質に関する問題があった。

経済的な理由から，数年間にわたって殺菌剂の使用 量が大きく減らされていた。この使用量を減少させた ことは, 全体的には抄紙機污れの形成に大きな影響を 与えなかった。しかし，この期間中に硫化水素の悪臭 に対する苦情が増加した。また，これと同じ期間に白 水チェストの擋找装置が撤去された。

他のある工場での爆発による致命的な事故が起こっ た際に，硫化水素の問題に対して関心が高まった。好 気性のプレート培養法での菌数值は, 高濃度の硫化水 素濃度と相関しなかった。毎週実施された硫酸塩還元 菌（SRB）の検査では，一貫して高レベルを示した。 硫酸掹還元菌は硫化水素を発生する代表的な菌である。 原料である段ボール古紙を，抄紙機からの回収水で 
溶解している場所では, 嗅覚検査によって $45 \mathrm{ppm} の$ 硫化水素港度が記録された。また，眝蔵チェストの付 近においても，更に高い濃度が検出された。

ここで,ヘッドボックスの $\mathrm{pH}$ は酸性であり,これ は多くの嫌気性菌の增殖が抑制されるものであった。

しかし, 再生水の $\mathrm{pH}$ は 7.2 7.6であった。この $\mathrm{pH}$ 範囲は嫌気性菌に理想的なものであった。工程水の温

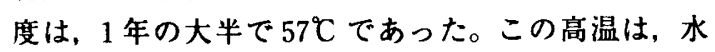
中の溶存酸素浱度が非常に低いことを意味していた。 これもまた嫌気性菌に良好な增殖条件をもたらしてい た。

この工場における状況は複雑であった。明らかに， 嫌気性菌によって生じる可能性がある安全上の問題が あることは明らかであった。殺菌戍によって微生物を 処理しても，経済的には操作性は改善できなかった。 そして, 嫌気性菌に伴う全ての問題を防止する保証は できなかった。そこで，嫌気性菌にとって好ましくな い環境にするための複合的解決法が提案された。この システムには硫酸バンドが使用されていた。硫酸バン ドは硫酸塩の供給源であり, 硫酸塩は硫酸塩還元細菌 の增殖を促進する。

そこで, 代替のケミカルプログラムが提案された。 また, 水の置換時間の短縮やチェスト内での貯留時間 の短縮と共に, 屋外チェストの擋拌の增強も提案され た。嫌気性菌の活性が高く問題が生じ易いチェストへ の殺菌剤の添加も提案された。

更に, Rowbottom の論文での推奨事項が検討され た5!。これは，製紙工場での嫌気性菌による問題の軽 減に関するものである。また，溶接等の火気作業を行 う前の爆発下限試験の実施も推奖された。

\section{6. 要 約}

製紙工場において，微生物によって起こる問題は複 雑である。単純なプレート培養法のみに頼って好気性
菌の測定を行うと問題の誤診を招く可能性がある。そ して, 誤った結論を招く可能性がある。製紙工場での 問題を解決するためには，抄紙系に生息している微生 物の環境による挙動を全体的に把握しておく必要があ る。

\section{参考文献}

1) W. G. Characklis and K. C. Marshall, Biofilms: A Basis for an Interdisciplinary Approach, in Characklis and Marshall, (eds.), Biofilms. John Wiley \& Sons Inc., pp 3-16. 1990

2) Davies, D.G.. M.R. Parsek, J.P. Pearson, B.H. Iglewski, J.W. Costerton, and E.P. Greenberg : "The Involvement of Cell-to-Cell Signals in the Development of a Bacterial Biofilm," Science, $280: 295$ 298 (1998).

3) Rice, L. E., Kehoe, V. M., and Robertson, L. R. : "The Diversity of Filamentous Bacteria in Paper Systems from Incoming Water to Wastewater Effluent." Tappi Environmental Conference Proceedings. Denver, Tappi Press. Atlanta, May (2000)

4) Anon. Standard Methods for the Examination of Water and Wastewater $17^{\text {th }}$ Edition. American Public Health Association, American Water Works Association, Water Pollution Control Federation, 1989

5) R. S. Rowbottom : "Bacteria Cause Fatal Explosion at Corrugating Medium Mill, " Pulp and Paper Canada 90 (4) 75 (1989).

6) L. R. Robertson and W. R. Schwingel : Microbial challenges unique to closed recycle paper systems. PIRA Proceedings, International Conference on Wet End Chemistry and COST Workshop. Gatwick 1997 


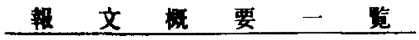

ウェットエンドにおける自動薬品制御の適用

一オンライン・チャージ計によるウェットエンドの最適化一

ミューテック・アナリティック GmbH ローランド・ビィアガー,リディア・クリステン・ブレイ

スペクトリス株式会社 BTG 事莱部 石原 健一

パルブ工程と漂白工程での浱度制御は正確で信頼できる結果を得られており，濃度は工程稼働率を向 上させるために制御されなければならない重要かつ基本的なパラメータである。抄紙機において，白水 浱度制御は業界標华としてみなされており，この制御戦略は効率的で有益であると証明されてきた。現

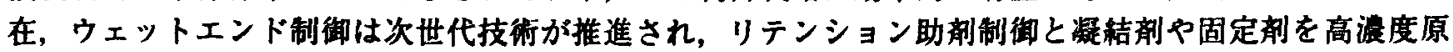
料エリアで使用したチャージ要求量制御を組み合わせることによりより良い効果を上げている。白水浱 度によるリテンション助剂制御は，チャージ要求量制御と平行に展開されており，製紙工程で使われる 全ての化学薬品が PM 走行性と稼䱂率に影霜を及ほすこと理解することが重要である。漂白に使用され る莱品がウエットエンドへ持ち込まれることは多々あり, リテンション助剂, 染料, 凝結唷と湿潤/乾 燥紙力製品の最終的な効果に影篅を与える。

本報は, ウエットエンド莱品制御分野での更なる理解を深め, リテンション制御とチャージ制御を解 明し，また二つの制御のギャッブに椅湾しをするものである。

(本文 38 ページ)

\section{製紙工業向け新型白水ろ過機の紹介}

株式会社萑原製作所 嫄境エンジニアリング事業本部 高橋 知広

水の再生・再利用の対象としては, その污染度の低さと水量の多さから, 抄紙白水の再利用が第一に 考えられる。一般に抄紙白水は水温が $40^{\circ} \mathrm{C}$ 程度と高く，この抄紙白水を再利用することは蒸気使用量 の削娍にもつながり，抄紙白水を再利用するメリットは大きい。また，この一方で，現状では抄紙白水 の再利用が進んでいない工場が多い状況にあり，今後抄紙白水再利用設備の霖要は㹡大が予想される。

抄紙白水の再利用技街としては，これまでにいくつかの技術が開発され実用化されてきているが，良 好な水留を安定して得られるという稓点から，現在まで砂ろ過がその中心となってきた。しかし，従来 のろ過機では，マッドポール形成に起因するろ床の閉塞やスライム障害などが起こりやすく，運転の維 持管理に問題を生じることがあった。

暂社では，白水ろ遏機における洗浄不良の問題を解決するため，这洗時にろ材の表層を港䢁できる擋 䢁機を設置した新型ろ過樴を開発した。本報はその概要を紹介する。

(本文 45 ページ)

\section{抄紙機における微生物問題の診断について}

\author{
オンデオナルコカンパニー リンダ・ロバートソン \\ オンデオナルコ ジャパン株式会社 石井 康正
}

抄紙機中では多くの微生物が增殖可能である。これら微生物は, 肉眼で見られる污れを形成して, シ 一ト久陥や穴, あるいは断紙も発生する。微生物は, パルプや各種製紙工程菓品の性能低下と腐敗を招 くこともある。この腐敗は, 䄉維の強度低下ゃ製品の品筫低下を招く異莫発生やデンブン粘度低下及び 
その他の多様な問題を起こすことがある。

トリプトンタルコース寒天培地やペトリフィルム (Petrifilms ${ }^{\mathrm{TM}}$ ) 培地による48時間培養等の様な単 純な好気性ブレート培養法では, 問題を生じる微生物の全てを把握できる分けではない。また，浮遊性 (Planktonic) の微生物については, その菌数値と装置表面での污れ付着量とは相関しない。装置表面 に付着してバイオフィルムを形成する微生物は, 浮遊性微生物とは異なる性質を持つ付着性（Sessile） と呼ばれるものである。

このような背累から, 微生物に関する問題を診断することが難しい。単純なプレート培養法のみに頼 って好気性菌の検出を行うと問題の誤診を招く可能性がある。そして, 誤った結論を招く可能性がある。 製紙工場での問題を解決するためには，抄紙系に生息している微生物の珢境による挙動を全体的に理解 しておく必要がある。

本報では一般に受入れられているブレート培䓹法の限界について論じ，3つのケーススタデイーを用 いて, 微生物に関する問題を解決するための診断方法を紹介する。

(本文 50 ページ)

\section{オンライン化による抄紙機の生産性向上 一LWC, SC，上質コート紙のオンライン化コンセブトー}

住友重機樴テクノフォート株式会社 製紙機械エンジニアリンタクルーフ 藤原 洋

抄紙機の生産性向上は多様な方法で実現できるが，最新技術を導入した場合より高い生産性の向上が 可能となる。その主要な技術として，オンライン化技術がある。これはオフライン工程をオンライン化 することで製造プロセスをシンブルにし，生産性の向上をはかるものである。

品質アップを考えない場合には，リールまで一貝したオンラインブロセスで䌘造することがもっとも 効果的な生産性向上策である。オンライン化は設備投資穆の削娍, ライン全長の短縮, ランニンクコス トの削娍にもつながる。最新の塗工抄機はほとんどがオンライン仕上げかフレコートを行っており， オンラインコーティンクは大きなリスクとはなっていない。また, ポリマーカバー及びオンラインマル チニッフカレンダの開発により，高速でのオンラインカレンタリンダでも良い表面性状を得ることが可 能となってきている。通紙についても，新しい通紙装置が開発されオンライン化のボトルネックではな くなっている。このような技術的進歩により，設備の目的や固別条件に合致すればオンライン化は生産 性向上に取も有効な手段となる。本辡ではオンライン化の現状を具体的なデータを交えて紹介するとと もに，オンライン化のコンセプト，オンライン化の特長, LWC.SC, 上質コート紙についてのオンライ ンレイアウト及び䔔用設濊を紹介する。

(本文 57 ベージ)

\section{三菱 MCCR/MJ カレンダ}

\section{三菱重工羓株式会社 広島研究所 鈴木 節夫}

オベレータフレンドリーで高生産性（高速*高効率）の抄紙機 MJ シリースのカレンタパートには， ロール内部に配置したマルチシューで高精度のキャリパ制御を行える三菱マルチシューCCロール (MCCR) とシューブレスの技術をカレンタに適用したシューカレンダを取り揃えている。

最近では，高品頎な印刷を実現するための表面品質，原料使用量を低減し剛性等の强度を維持する蓠 高紙の要求が強くなってきており，蓠高で高品犋を特徽とする MJ カレンタへの期待が高まっている。

実機フィールドデータ,パイロット機でのトライアルデータから三荾マルチシューCCロール及び $\mathrm{MJ}$ カレンタの特幑と性能の概要を路介する。

(本女 65 ページ) 